\title{
The Contributions of Nawawi al-Bantani In the Development of National Law of Indonesia
}

\author{
Ahmad Sanusi
}

\begin{abstract}
Abstrak: The Contributions of Nawawi al-Bantani In the Development of National Law of Indonesia. This study examines the thoughts of Sheikh Nawawi al-Bantani, a great Banten scholar who lived in 1813-1897 AD. The aim is to find out about his thoughts on several legal issues, especially those related to family law. This study is fully literary using the content analysis method as an analytical tool. This study concluded that Sheikh Nawawi al-Bantani tended to follow the Shafi'i school. This can be seen from his thoughts when discussing family law issues, ranging from marriage contracts, marriage conditions, guardians and witnesses, to divorce problems and its legal consequences. When discussing the position and role of a husband in a household, al-Bantani stressed that a husband is a leader in his household. He is obliged to fulfill all the needs of his wife and children, especially those related to food, clothing, residence, education and other needs. Al-Bantani's thoughts were subsequently adopted into positive law in Indonesia, especially in Law No. 1/1974 concerning marriage and Compilation of Islamic Law (KHI), which become his biggest contribution in the development of National Law.
\end{abstract}

Keywords: Syekh Nawawi, al-Bantani, fiqh munâkahât, Islamic law, Indonesia

\begin{abstract}
Abstrak: Kontribusi Syekh Nawawi al-Bantani dalam pembangunan Hukum Nasional di Indonesia. Studi ini menelaah pemikiran Syekh Nawawi al-Bantani, seorang ulama besar Banten yang hidup pada tahun 1813 - $1897 \mathrm{M}$. Tujuannya adalah untuk mengetahui pemikiran beliau tentang beberapa masalah hukum terutama yang berkaitan dengan hukum keluarga. Studi ini sepenuhnya literair dengan menggunakan metode konten analisis sebagai alat analisisnya. Penelitian ini menyimpulkan bahwa Syekh Nawawi al-Bantani cenderung mengikuti mazhab Syaf'i. Hal ini terlihat dari pemikiran-pemikiran beliau ketika membahas masalah Hukum Keluarga, mulai dari masalah pernikahan, syarat-syarat nikah, wali dan saksi nikah hingga ke masalah perceraian dan akibat hukumnya. Ketika membahas kedudukan dan peran seorang suami dalam suatu rumah tangga, al-Bantani menegaskan bahwa seorang suami adalah pemimpin rumah tangga. Ia berkewajiban untuk memenuhi kebutuhan isteri dan anak-anaknya terutama yang berkaitan dengan makanan, pakaian, tempat kediaman, dan pendidikan. Pemikiran al-Bantani ini selanjutnya diadopsi ke dalam hukum positif di Indonesia khususnya ke dalam UU No. 1/1974 tentang perkawinan dan Kompilasi Hukum Islam (KHI), yang merupakan sumbangan terbesar beliau dalam pembangunan Hukum Nasional.
\end{abstract}

Kata Kunci: Syekh Nawawi, al-Bantani, fikih munâkahât, hukum Islam, Indonesia

Universitas Islam Negeri Sultan Maulana Hasanuddin Banten

Jl. Jendral Sudirman No. 30 Panancangan Cipocok Jaya, Sumurpecung, Serang, Banten 42118

E-mail: ahmad.sanusi@uinbanten.ac.id 


\section{Introduction}

The great name of Syekh Nawawi al-Jawi al-Bantani has already been familiar among Indonesian Muslims, especially among the Salafiyah Islamic Boarding Schools of Indonesia and in some Middle Eastern countries as well. He was a loyal adherent of Shafi'iyah School of Law and even frequently associated with the classic Muslim scholar of Shafi' $i$ himself. His works spread across the pesantren (traditional Islamic boarding school) and many of them are still being used as handbooks or teaching materials. His works also become references in various disciplines—ranging from Islamic theology, Law, Quranic Exegesis, until Sufism-and create a mainstream of Islamic studies developed in several Islamic boarding schools under the religious organization of Nahdhatul Ulama (NU). ${ }^{1}$

Nawawi al-Bantani is included in the great traditional scholars of Indonesia. ${ }^{2}$ His writings also cover a wide range of disciplines in Islamic studies, not only on figh (Islamic jurisprudence) but also on theology and Sufism. The works become essential in the study of Islam and have been inspiring a number of Muslim scholars to develop a new method in the study of figh and have become a great contribution to the development of Islamic Law in Indonesia.

One of the important works of Nawawi in Islamic jurisprudence is fiqh al-munâkahât (the law of marriage). In his book entitled 'Uqûd

${ }^{1}$ Regarding the history of Banten scholars and their dynamics, see the works of Sartono Kartodirdjo, 'Le Leadership Dans La Révolte Des Paysans de Banten, 1888', Archipel, 50.1 (1995), p. 123-130. Nina Herlina Lubis, Banten Dalam Pergumulan Sejarah: Sultan, Ulama, Jawara (Jakarta: LP3ES, 2004). Abdul Hamid Abdul Hamid, 'Memetakan Aktor Politik Lokal Banten Pasca Orde Baru: Studi Kasus Kiai dan Jawara di Banten', POLITIKA: Jurnal Ilmu Politik, 1, no. 2 (2013), p. 32-45. Moch Nur Ichwan, 'The Local Politics of Orthodoxy: The Majelis Ulama Indonesia in the Post-New Order Banten', Journal of Indonesian Islam, 6, no. 1 (2012), p. 166-194. Asep Muslim and others, 'Dinamika Peran Sosial Politik Ulama dan Jawara di Pandeglang Banten', MIMBAR, Jurnal Sosial dan Pembangunan, 31, no. 2 (2015), p. 461-474. Mohamad Hudaeri, 'Tasbih dan Golok: Studi Tentang Kharisma Kyai \& Jawara di Banten’, Istiqro, 2, no. 01 (2003), p. 57-87. Mamat Slamet Burhanuddin, 'KH Nawawi Banten (w. 1314/1897) Akar Tradisi Keintelektualan NU', MIQOT: Jurnal Ilmu-Ilmu Keislaman, 34, no. 1 (2010). A. Adaby Darban, 'Ulama Jawa dalam Perspektif Sejarah', Jurnal Humaniora, 16, no. 1 (2010), p. 27-34.

2 Related articles that discuss and focus on Imam Nawawi al-Bantani read the works Samsul Munir Amin, 'Syaikh Nawawi al-Bantani Tokoh Intelektual Pesantren', Manarul Qur'an, 13, no. 2 (2017), p. 138-150. Abd Al Rahman, 'Nawawi al- Bantani; an Intellectual Master of The Pesantren Tradition', Studia Islamika, 3, no. 3 (1996). 
al-Lujain, Nawawi al-Bantani discusses the position and the role of a husband in a household. In interpreting the word "Qowwâmuna" in the Surah al-Nisa verse 34, al-Bantani interprets it as "the people who have the power to educate", thus giving the impression that the position of the male is superior to female in all areas of life. This tendency, then, is implied in his thinkings on several issues dealing with the law of marriage. ${ }^{3}$

Syekh Nawawi also introduced a number of al-Riyadh's textbook to Indonesian Muslims. Among them is al-Badî'ah fi Ushîl al-Dîn wa Ba'dh Furû al-Sharîah. This book explaines the obligations and the choices of religious teachings. Not much is known about the author, Muhammad Hasbullah. Perhaps he was contemporary with or slightly older than Nawawi al-Bantani. The author was only known for his sarah Nawawi, Tsamar al-Yanîah.

Nawawi al-Bantani managed to bring the majority of Indonesian muslim over the Shafi'i madzhab (school of Islamic jurisprudence). Besides

${ }^{3}$ Husein Muhammad, 'Figh Perempuan', Refleksi Kiai Atas Wacana Agama dan Jender,( Yogyakarta: LKiS Kerjasama dengan Rahima dan Ford Foundation, 2001). Mustofa Bisri, 'Ini 'Uqûd al-Lujjayn Baru: Ini Baru 'Uqûd al-Lujjayn', in Sinta Nuriyah A. Wahid et al, Wajah Baru Relasi Suami Istri: Telaah Kitab 'Uqûd Al-Lujjayn, (Yogyakarta: LKIS, 2001). Bisri; Husein Muhammad, 'Kajian Atas Kitab Uqud al-Lujain', Tashwirul Afkar, 1999, p. 94-100; Eka Srimulyani, 'Muslim Women and Education in Indonesia: The Pondok Pesantren Experience', Asia Pacific Journal of Education, 27, no. 1 (2007), p. 85-99. Haidlor Ali Ahmad, 'Kesetaraan Gender dan Pemberdayaan Perempuan di Pondok Pesantren', Penamas (Jurnal Penelitian Agama dan Kemasyarakatan), 2000, p. 51-61. Haidlor Ali Ahmad, Kesetaraan Gender, and Pemberdayaan Perempuan di Pondok, 'Alhadar, Ivan, Pesantren Between Tradition and Industrial-Urban Challenge in Manfred Oepen and Wolfgang Karcher (Eds.), The Impact of Pesantren in Education and Community Development in Indonesia, Friedrich Naumann Stiftung: Indonesian Society for Pesantren and Community Development, P3M): Technical Unversity Berlin, Jakarta, 1998, p. 99-109.', Jurnal Perempuan, 1999, p. 7-18. Suwarjin Suwarjin, 'Kitab Syarah dan Tradisi Intelektual Pesantren', Jurnal Ilmiah Mizani: Wacana Hukum, Ekonomi dan Keagamaan, 4, no. 2 (2018). Zaenul Mahmudi, 'Fikih di Pesantren Salaf (Strategi Pengembangan Fikih Salaf di Pesantren Hidayatul Mubtadi' in Lirboyo Kediri)', El-QUDWAH, 2012. Toni Pransiska, 'Pendidikan Islam Transformatif Syeikh Nawawi al-Bantani: Upaya Mewujudkan Generasi Religius-Saintifik', Jurnal Ilmiah Didaktika: Media Ilmiah Pendidikan dan Pengajaran, 18, no. 2 (2018), p. 172-188. Silvia Riskha Fabriar, 'Potret Perempuan dalam Film Perempuan Berkalung Sorban', Sawwa: Jurnal Studi Gender, 9, no. 1 (2013), p. 27-44. Hamam Burhanuddin, 'Pendidikan Berperspektif Gender di Pesantren', Al-Murabbi: Jurnal Studi Kependidikan dan Keislaman, 2, no. 1 (2015), p. 111-132. KH Husein Muhammad, Fiqh Perempuan: Refleksi Kiai Atas Wacana Agama dan Gender (Yogyakarta: LKiS Pelangi Aksara, 2001). Moh Toriqul Chaer, 'Pesantren dan Pendidikan Gender', Journal Islam Indonesia, 6, no. 2 (2016), p. 104-104. 
writting a number of book based on the Shafi'i legal thought, al-Bantani also introduce several books written by many promininent Shâfi'iyyah scholars into his circles. It was under such situation that the majority of Islamic mass organizations in Indonesia prefer to adhere the Shafi' $i$ rather than the other three madzhabs such as: Hanâfiyyah, Mâlikiyyah and Hanâbilah. Indeed, as Hodgson states, as the fiqh has been cristalized within the Ummah, a great number of Muslims, except Syi'ah, become the follower of one of the four madzhabs. ${ }^{4}$

Nawawi al-Bantani wrote a number of books of fiqh, among others one is entitled Nihâyat al-Zain. This book is a commentary of the Qurrat al-'Ain, a book written by the 16th century South Indian scholar, Zain ad-Dîn al-Malibari (975 AD). This Indian scholar was a student of Ibn Hajar al-Haitami (died 973 AD), the writer of Tuhfah al-Muhtâj, but the Qurrat and It's commentary later written by al-Malibari himself not based on the Tuhfah. The Qurrat al-Ain was commented and rewritten by another author to Fath al-Muin. Two people who were contemporaries of Nawawi Banten in Mecca, but younger, wrote Hašiyah (notes) on Fath al-Mu'in. Sayyid Bakri bin Muhammad Šatha al-Dimyathi wrote four volumes of I'anah al-Thâlibin which contained the author's notes and a number of fatwas from the contemporary Mufti Šhafi'i in Mecca, Ahmad bin Zaini Dahlan.

\section{The Biography of Nawawi al-Bantani}

The full name of Nawawi al-Bantani is Abû Abdul Mu'thi Muhammad Nawawi bin Umar bin Arabi, also known as Nawawi al-Jawi al-Bantani al-Šhâf'i. Syaikh Nawawi was born in a village called Tanara, Tanara Subdistrict, Serang District, Banten Province. His father was Umar, a ruler who led the mosque. ${ }^{5}$ From the pedigree, according to Chaidar, Nawawi was the descendant of the 12th Sultanate of Maulana Syarif Hidayatullah (Sunan Gunung Djati, Cirebon), a descendant of Maulana

\footnotetext{
${ }^{4}$ Marshall GS Hodgson, The Venture of Islam: Iman dan Sejarah dalam Peradaban Dunia (Jakarta: Paramadina, 2012), p. 133-34.

5 Denys Lombard, 'Zamakhsyari Dhofier, Tradisi Pesantren, Studi Tentang Pandangan Hidup Kyai', Archipel, 28, no. 28 (1984), p. 220-220.
} 
Hasanuddin's son (Sultan Banten I) named Sunyararas (Tâjul 'Arš). His genealogy connected to the Prophet Muhammad. Through Imam Ja'far al-Şodiq, Imam Muhammad al-Bâqir, Imam 'Ali Zainal Abidin, Sayyidina Husain, Fatimah al-Zahra, and Prophet Muhammad Saw. ${ }^{6}$

His complete genealogy is as follows: Nawawi, bin Umar, bin Arabi, bin Ali, bin Jamad, bin Janta, bin Masbuqil, bin Masqun, bin Maswi, bin Tajul Arš (Prince Suryararas), bin Maulana Hasanuddin, bin Maulana Syarif Hidayatullah (Sunan Gunung Djati Cirebon), bin Amiruddin Abdullah, bin Ali Nuruddin, bin Maulana Jamaludddin Akbar Husain, bin Imam Sayid Ahmad Šah Jalal, bin Abdullah Adzmah Khan, bin Amir Abdullah Malik, bin Sayyid Alwi, bin Sayyid Muhammad Şahib Mirbath, bin Sayyid Ali Khali Qasim, bin Sayyid Alwi, bin Imam Ubaidillah, bin Imam Ahmad Muhajir Ilallahi, bin Imam Isa an Naqib, bin Imam Muhammad al Baqir, bin Imam Ali Zainal Abidin, bin Sayyidina Husain, bin Fatimah al-Zahra, binti Muhammad Saw. ${ }^{7}$

Nawawi gets the title Sayyid 'Ulama Hejaz. Sayyid means Lord of Muslim scholars while Hijaz is the region in Saudi Arabia, which includes Mecca, Jeddah, and Medina. In Mecca, Nawawi was better known as al-Bantani or al-Jawi, as listed in his books. The name Al-Bantani shows that he was from Banten, while the name al-Jawi indicates Javanese people, a term for archipelagic migrants because the name of Indonesia at that time was unknown. Recently, the Islamic boarding schools call the cleric who was also dubbed al-Fakih as Nawawi Banten.

Nawawi al-Bantani married with Nyai Nasimah, a native of Tanara, Banten. From this marriage, Nawawi al-Bantani was endowed with three daughters namely, Nafisah, Maryam, and Rubiah. Nyai Nasimah died before Nawawi al-Bantani died. But when and where exactly she was buried is not known. By the late eighties, Nawawi al-Bantani married again with Nyai Hamdanah, KH. Soleh Darat Semarang daughter's at that time was between seven and 12 years old. From the marriage, Nawawi

${ }^{6}$ Chaidar, Sejarah Pujangga Islam Syaikh Nawawi Al-Bantani Indonesia', (Jakarta: CV Sarana Mulia, 1978), p. 5.

7 Samsul Munir Amin, Sayyid Ulama Hijaz: Biografi Syaikh Nawawi al-Bantani (Pustaka Pesantren, 2009), p. 11-12. 
al-Bantani was blessed with a princess named Zuhroh. An assumption that Nawawi also married an Arab woman was not convincing as it was not supported by any sources. ${ }^{8}$

Nawawi died in $1314 \mathrm{H} / 1896 \mathrm{AD}$ at the age of 84 in Mecca. He was buried in Ma'la near the grave of Siti Khadijah, Ummul Mu'minin, the wife of the Prophet Muhammad PBUH. As pride in Java, especially in Banten, Muslims in Tanara Village of Tirtayasa Banten, each year on the last Friday of the month of Syawal, always hold a haul event to commemorate Nawawi al-Bantani. ${ }^{?}$

\section{Educational Background}

Nawawi lived within the clergy. His father was one of the great clerics in the Tanara village. He taught his sons, Nawawi, Tamim, and Ahmad directly. From his father, Nawawi studied the basic knowledge of Arabic, Fiqh, and Tafsir. Then Nawawi studied to Haji Sahal, a famous kyai in Banten. From Haji Sahal, Nawawi continued to study with Raden Haji Yusuf, a famous scholar in Purwakarta area near Karawang. After that, Nawawi studied at a pesantren in Cikampek area and intends to study Arabic. From there Nawawi returned to his hometown and taught at his father's pesantren. ${ }^{10} \mathrm{He}$ had memorized the whole Quranic verses when he was 18 years old.

In $1830 \mathrm{M} . / 1347 \mathrm{H}$, two years after his father died and he was 15 years old, al-Bantani went to Mecca to perform the pilgrimage. At first, he intended only to perform the pilgrimage, but eventually, he was interested in studying in Mecca. There he lived for about 3 years before he returned to his homeland. ${ }^{11}$ In $1855 \mathrm{AD}$, after settling in

${ }^{8}$ Abdurrahman Wahid and Sinta Nuriyah, Wajah Baru Relasi Suami Isteri: Telaah Kitab 'Uqud al-Lujjayn (Yogyakarta: LKiS, 2001), p. 208.

${ }^{9}$ Ishom el Saha, Intelektualisme Pesantren: Potret Tokoh dan Cakrawala Pemikiran di Era Pertumbuhan Pesantren (Yogyakarta: Diva Pustaka, 2003), p. 15

${ }^{10}$ Qouted from several sources: Yuyun Rodiana, Nawawi al-Bantani: Riwayat Hidup dan Sumbanganya Terhadap Islam (Jakarta: Skripsi S1, Fakultas Sastra Universitas Indonesia, 1990), p. 18. Chaidar, Sejarah Pujangga Islam Nawawi al-Bantani Indonesia, p. 29-30, Samsul Munir Amin, Sayyid Ulama Hijaz, p. 21-23.

${ }_{11}$ Karel A. Steenbrink, Beberapa Aspek tentang Islam di Indonesia Abad ke-19 (Jakarta: Bulan Bintang, 1984), p. 236; compare with Chaidar, Sejarah Pujangga Islam Nawawi al-Bantani 
Indonesia for about 22 years, al-Bantani came back to Mecca and stayed there until he died. ${ }^{12}$ According to C. Brockelman, Nawawi decided to return to Mecca, because he felt uncomfortable with the conditions in his neighborhood in Banten. In addition, he also felt that the space for his movement was not free because of the Dutch colonial who always watched the movements of the ulama, especially the alumnus of Mecca. In Mecca, he learned Islam from a number of prominent teachers, such as Sayid Ahmad Nahrawi, Sayid Ahmad Dimyati, Ahmad Zaini Dahlan, Muhammad Khatib al-Sambasi, Abdulghani Bima, Yusuf Sumbulaweni, and Abdul Hamid ad Daghastani. Besides in Mecca, He also spent his life studying Islam in Medina, Egypt, and Syria. ${ }^{13}$

\section{The Students of Nawawi al-Bantani}

As a person who mastered a deep knowledge of Islam, Nawawi felt obliged to teach the knowledge he had. According to some sources, Nawawi began actively giving teachings in 1860-1870. He did it only in his spare time because between those years he also was busy writing books. Nawawi taught several sciences including Fiqh, Tafsir, Tasawuf, Aqidah, and others at the Grand Mosque. His students were no less than 200 people, coming from various countries, including Indonesia. From Indonesia his students included:

1. K.H. Hasyim Asy'ari, was born in February 1287/1871 AD, in Gedang, Jombang, East Java. A prominent founder and caretaker of the Tebuireng Islamic Boarding School, Jombang, East Java. He was also the founder of the Nahdhatul Ulama (NU) organization, the largest Islamic social organization in Indonesia to date. He studied with Nawawi while in Mecca. According to Chaidar KH. Hasyim Asy'ari greatly admired Nawawi and even Hasyim shed tears when he remembered Nawawi. ${ }^{14} \mathrm{KH}$. Hasyim Asy'ari died in 1947 M,

Indonesia, p. 29-30. Samsul Munir Amin, Sayyid Ulama Hijaz, p. 7.

${ }^{12}$ Snouck Hurgronje, Mekka in the Latter Part of the 19th Century: Daily Life, Customs and Learning. The Moslims of the East-Indian Archipelago (Leiden: Brill, 2006), p. 268.

${ }^{13}$ Carl Brockelmann, Al-Nawawi', The Encyclopaedia of Islam (Leiden: Brill Archive, 1954).

${ }^{14}$ Quoted from several sources: Lathiful Khuluk, Fajar Kebangunan Ulama : Biografi KH. 
because of illness in Tebuireng Jombang, East Java and was buried in the Tebuireng Jombang Islamic Boarding School Complex.

2. K.H. Khalil, Bangkalan, Madura, East Java. The spiritual scholar who is believed by many as one of the waliyullah. He was the representative of Thoriqoh Qodiriyah Naqsabandiyah in East Java. Khalil was born in Bangkalan Madura in 1819 and died in 1925. Mbah Khalil met Nawawi in Mecca.

3. K.H. Mahfudh at-Tarmizi, Tremas, East Java. He was born in the East Java Pacitan Tremas in 1874 and died in Mecca in 1919.

\section{His Works}

Throughout of his life, Nawawi had written, various books in various fields of Islamic studies, such as Tafsir, Fiqh, Usûl ad-dîn, Tauhid (theology), Sufism (mysticism). Prophet's life, Arabic grammar, Hadits, and Akhlaq (Islamic morality). ${ }^{15}$ The number of his works, as shown by many writers, is more than 100 books, although Bruinessen only managed to collect 70 pieces. $^{16}$

The books of Nawawi al Bantan that author can collect of 40 books namely: al-Simâr al-Yâni'ah fi al-Riyâdl al-Badîah (Fiqh), Fath al-Mujîb, Sarh 'ala al-Sarbini (Fiqh), al-Tausìh, Sarh 'ala Fath al-Qarîb (Fiqh), Nihâyat al-Zain fî Iršâd al-Mubtadîn (Fiqh), Sulâm al-Munâjat Šarh 'ala Safinat al-Şalat (Fiqh), Kašifat al-Saja'(Fiqh), 'Uqûd al-Lujain fî Huqûq al-Zaijain (Fiqh), Sulùk al-Jadah (Fiqh), Qût al Habib al-Gharîb (Figh), Bahjatul al-Wasâil, Šarh al-Risâlah al-Jamîah baina al-Uşûl al-Dîn wal Fiqh wa al-Tasawuf (Tauhid Fiqh, Tasawuf), Nur al-Dzalam Šarh

Hasyim Asy'ari (Yogyakarta: LKiS Pelangi Aksara, 2000), p. 20. Chaidar, Sejarah Pujangga Islam, p. 29-30. Samsul Munir Amin, Sayyid Ulama Hijaz, p. 21-23. Mahrus As'ad, 'Pembaruan Pendidikan Islam K.H. Hasyim Asy’ari', TSAQAFAH, 8, no. 1 (2012), p. 105-34 <https:// doi.org/10.21111/tsaqafah.v8i1.18>. Lathiful Khuluq, 'K.H. Hasyim Asy'ari's Contribution to Indonesian Independence', Studia Islamika, 5, no. 1 (1998) <https://doi.org/10.15408/sdi. v5i1.760>. Syamsul A'dlom, 'Kiprah KH.Hasyim Asy'ari dalam Mengembangkan Pendidikan Agama Islam', JURNAL PUSAKA, 2, no. 1 (2014) <http://ejournal.alqolam.ac.id/index.php/ jurnal_pusaka/article/view/14>..

${ }^{15}$ Carl Brockelmann, The Encyclopaedia of Islam.

${ }^{16}$ Abdurrachman Mas'ud, Dari Haramain ke Nusantara: Jejak Intelektual Arsitek Pesantren (Jakarta: Kencana, 2006), p. 128. 
'ala Man al-Umah bi 'Aqidah al-'Awam (Tauhid), Al-'Aqdus Samin, Šarh 'ala Mandzûmat al-Sittîn Masâlatan al-Musamma bi al-Fath al-Mubîn (Tauhid), Tijân al-Darari, Šarh 'ala al-'Alim al-'Allamah Ibrahim al-Bajuri fi Taubî̀ (Taubid), Fath al-Majîd Sarh 'ala Dur al-Farîd fî̀ al-Tauhîd (Tauhid), Mirqât al-Su’ûd Tašdîq(Tauhid), Qami' al-Thugyân (Taubid), Al- Futûh al-Madaniyah (Taubid), Fath al-Ghafir al-Hatiyah (Tauhid), Qathrul Gais (Tauhid), al-Nahjah al-Jayyidah li Hâlli Naqawâti al-Aqîdah (Tauhid), Hilyatus Šibyân (Tauhid), Sarh ala al-Manzûmat Muhammad al-Dimyati(Tauhid), Salâlim al-Fudhala, Sarh 'ala Mandzûmat al-Azkiya (Tasawuf), Marâqil Ubûdiyah, Sarh 'ala Bidâyat al-Hidâyah (Tasawuf), Misbah al-Dhalâm (Tasawuf), Dzariatul Yaqîn (Tasawuf), Fath al-'Arifin (Tasawuf), Tafsir al-Munîr li Ma'âlim al-Tanzîl (Tafsir), Tanqîh al-Qaul al-Hatsis, Šarh 'ala Lubab al-HadiSt (Hadis), Targhib al-Mustaqîn, Sarh 'ala Manzûmat Sayyid al-Barzanji Zainal 'Abidin fî Maulid Sayyidi alAwwalîn (Tarih), Madârij al-Su'ud Šarh 'ala Maulid al-Nabâwi (Tarih), Fath al-Şamad, Sarh 'ala Maulid al-Nabâwi (Tarih), Al-Ibriz al-Zani fì Maulidi Sayyidina (Tarih), Bughyatul Anâm (Tarih), Sarh al-Burdah (Tarih), Al-Fuşûs al-Yaqutiyah (Lughah), al-Riyâd al-Fauliyah (Lughah), Kašf al-Maruthiyah (Nahwu), Lubab al-Bayân (Balaghah). ${ }^{17}$

${ }^{17}$ Some of these books are used as a topic of studies by some intellectuals, among them are: Sukhairu Sulaiman, 'Al-Qira'at al-Mutawatirah dan Kesannya Terhadap Pentafsiran al-Qur'an : Kajian Terhadap Kitab Marah Labid Li Kashf Ma'na al-Qur'an al-Majid Karangan Nawawi Al-Bantani Tumpuan Terhadap Surah al-Baqarah (unpublished masters, University of Malaya, 2013) <http://studentsrepo.um.edu.my/5323/>. Ainaul Mardhiyyah, 'Konstruksi Seksualitas Perempuan dalam Literatur Pesantren Klasik: (Studi Terhadap Kitab Uqud al-Lujjayn Karya Nawawi al-Bantani)', Palastren Jurnal Studi Gender, 6, no. 1 (2016), p. 57-88 <https:// doi.org/10.21043/palastren.v6i1.978>. Muhammad Ridwan Hidayatulloh, Aceng Kosasih, and Fahrudin Fahrudin, 'Konsep Tasawuf Syaikh Nawawi al-Bantani dan Implikasinya Terhadap Pendidikan Agama Islam di Persekolahan', Tarbawy : Indonesian Journal of Islamic Education, 2, no. 1 (2015), p. 1-15 <https://doi.org/10.17509/t.v2i1.3373>. Ahmad Fatah, 'Mendambakan Paradigma Kesetaraan dalam Pernikahan (Telaah Kritis Terhadap Kitab Uqûd al-Lujjain)', Jurnal Penelitian, 8, no. 2 (2014) <https://doi.org/10.21043/jupe.v8i2.842>; Srimulyati, "Sufism in Indonesia: An Analysis of Nawawi al-Bantani's Salâlîm al-Fudalâ." PhD diss., Tesis--McGill University, Montreal Kanada, 1992. 


\section{The Law of Marriage: A Contribution of Nawawi al Bantani to the Development of Islamic Law in Indonesia}

\section{a. Definitions of Marriage}

Nawawi al-Bantani defined marriage which he stipulated as a mother of contract, he defines it as follows:

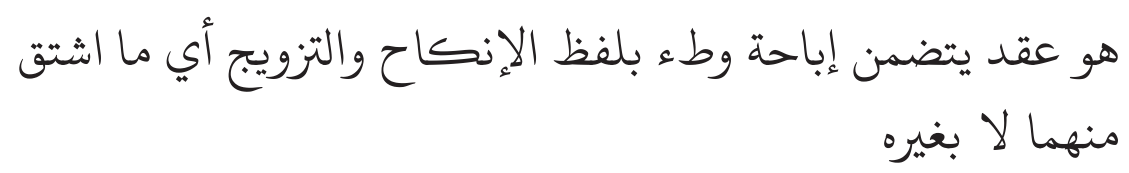

Marriage is a contract with a lafadz of marriage (a marriage utterance) or zawaj or a word taken from the marriage word or zawaj to allow intercourse

Nawawi al-Bantani views that marriage contract does not mean to give the please to one party only (male or husband), but to both parties, husband and wife. The wife has the right to be exhilarated by her husband and the husband is obliged to fulfill it and vise versa. So, from this respect, there must be a balance between the spouse. Unfortunately, this view was not reflected in his works as when he talked about the rights and obligations of the wife, al-Bantani tended to position a wife inferior to her husband.

Nawawi al-Bantani, like the majority of Muslim jurists, regarded the marriage as a sunnah or mustahab (highly recommended). He stated that marriage is a mustahab for those who are capable or incapable of dowry and their livelihood. For those who are incapable, however, they are recommended to restrain the desire by fasting. If fasting fails to restrain from the desire, then he is recommended to marry so as to protect him from immoral deeds (adultery).

Based on this view, Nawawi al-Bantani asserted that the basic purposes of marriage:

1. To prevent from meanness (Saddu al-Żarìah). The marriage is a way to avoid adultery because the only institution besides the milkulyamin (owning bondslave) that legalizes sexual relations is the marriage. As keeping away from Zinâ (adultery) or anything that can lead to it (mukadimah) is obligatory, then the marriage is obligatory. Similarly, the legitimate ruj $\hat{u}$ (return) of talaq (divorce) is ihtiyât (circumspection) to the excessive use of talaq. 
2. To open the way of livelihood and offspring (Saddu al-Żarîab). The marriage is a medium encouraging sustenance search because in the marriage institution there is an economic potential. Similarly, it is a medium of heredity because obtaining the offspring is the common desire of everyone whereas the only legal way to obtain it is a marriage. Nawawi al-Bantani referred his views about marriage as sustenance to the Prophet word Daelami from Ibn Abbas: (Look for sustenance by reason of marriage). It means: (indeed the marriage brings blessings and pours out sustenance if the intention is true).

b. Monogamy and Polygamy

Good marriage law is one that can guarantee and maintain the essence of marriage in any situation that occurs or that might occur. Marriage is not a physical relationship between two types of animals, as well as not a spiritual relationship between two angels. Marriage is a human relationship between men and women to meet life with all its problems.

According to Nawawi, the principle of marriage in Islam is the balance between monogamy and polygamy. In the beginning, the "order" of the marriage is polygamy (not monogamy). This thought appears in his interpretation of verse 3 of al-Nisa'.

c. The Children Marriage

The majority of the Muslim jurists, including Šhi'ah Ja'fariyah, allow Children Marriages because they do not require bâligh (maturity) as a condition for of marriage.

They argue, that the Qur'an has declared it legitimate and must carry out all its demands, namely on the word of God:

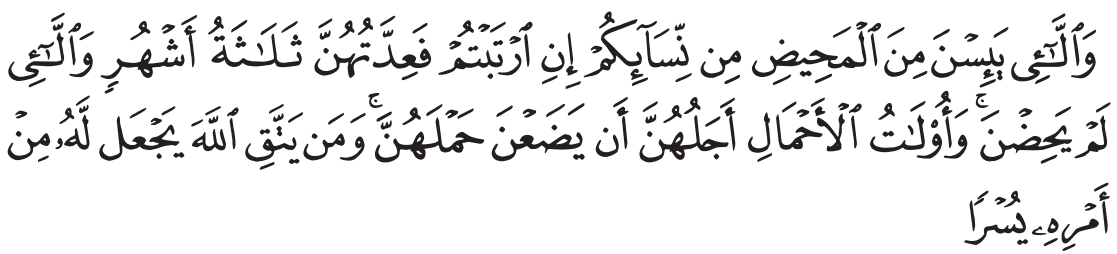

"And the women who do not menstruate (menopause) among your women if you are in doubt (about their idah), their idah is three months; and so women who are not menstruation. (al-Thalaq [65]: 4). 
Other scholars such as Ibnu Šabramah, Utsman, and Abu Bakr alAsham, forbid the marriage of young children and consider them to be false. Because the Qur'an in Surat al-Nisa [4]: 6 clearly asserts that marriage for an adult (bâligh) and that maturity is a sign of childhood end. When marriage is possible for a child, the ending of the prescribed age of the child is meaningless. The rational reason, that marriage is intended for survival, have offspring, and form a family. These purposes of marriage will not be achieved in the marriage of young children which seems only like a game, or even will cause harm. Therefore, it will not bring any good if the guardians carry it out.

According to Nawawi al-Bantani, as the majority of Muslim jurists view, the child marriage is legitimate if it is conducted by her aqrob wali (the closest guardians). For women under or above the absolute age, there must be a guardian; As for a small boy (under age), his marriage depends on his father and so on the upward line (grandfather and so on) even for the four wives, in order to realize his father's good intentions.

This statement implies that a young boy may marry a woman, but his marriage is performed by his father or his grandfather as his guardian, even with a marriage with four wives if it is aimed at goodness. Nawawi al-Bantani stated: "Let the child obey the order of his parents; everything that is governed by both parents or one of both (father or mother), must be obeyed even though the injunction harms the child, as long as it does not include the evil to Allah commandment".

The opinion of Nawawi al-Bantani and the majority of scholars over the legitimacy of the marriage of minors, for some reasons, were no longer relevant to our days. Because, after all, marriage is not just bringing together two children from different families, but it must be seen from the purposes of marriage itself because that in the fiqh munâkahât the principle of kafaah must be fulfilled.

Currently, the Marriage Act in Muslim countries contains the provisions of a minimum age of marriage. In Chapter II Articles 7 of KHI it is stated: A marriage is only permitted if the prospective groom has 
reached the age of 19 (nineteen) years and the prospective bride has reached the age of 16 (sixteen) years. Similarly, in Chapter IV article 15 of the Islamic Law Compilation (KHI) it is stated that for the sake of the welfare of families and marriages, a marriage is possible only when the prospective bridegroom attain the age specified in Article 7 regulation No. 1/1974 i.e prospective husbands are at least 19 years old and prospective wives are at least 16 years of age.

In the marriage law of a number of Arab countries, Syria for instance, the provision is almost the same as the Indonesian Law which regulates the marriage age limit for a prospective groom is 18 years and for a prospective bride is 16 years old.

d. Inter-religious Marriage

The law of marriage between a Muslim woman and a non-Muslim man, either ahl al-kitâb (The People of Books) or mušyrik (infidels), is agreed upon by the lawmakers that it is forbidden/illegitimate. In contrast, when discussing the marriage between a Muslim man and a non-Muslim woman, ahl al-kitâb, Muslim the scholars disagree with the so-called women ahl al-kitâb. In the view of Nawawi al-Bantani, Muslim women are forbidden to marry a non-muslim men, either abl al-kitâb or musyrik. Whereas a Muslim man can marry women either ahl al-kitâb or mušyrik. ${ }^{18}$ However, Nawawi is more inclined to the opinion that it is possible to marry the ahl al-kitâb woman only if she has converted to Islam as it is based on the hadith that the Prophet PBUH did not marry Sofia and Roihanah except after they both converted to Islam.

Nawawi also explains that the permission to marry abl al-kitâb is only for the people who holds the Taurat and the Injil before the ascension of the Qur'an. Such is according to the Shâfi'i madzhab which is in contrast to the other three schools. ${ }^{19}$ Thus, al-Bantani is more likely to forbid marrying the the present ahl al-kitâb woman.

${ }^{18}$ Nawawi al-Jawi, Nihayat al-Zain Fi Irsyad al-Mubtadiin (Dar Ihya al Kutub al Arabiya), p. 183.

${ }^{19}$ Nawawi, al-Tafsir al-Munir Maroh Labid Tafsir al-Nawawi (Bayrut: Dar Ihya al-Kutub al-Arabiyah, n.d.), Juz I, p. 139. 
Similarly, in the chapter 2 Law of Marriage No.1/1974 it is stated that a marriage is valid if it is done according to the law of each religion and belief. Thus it is not permissible to marry different religious follower even though from ahl al-kitâb. Such a provision is clearly parallel to the Syafei madzhab as it revealed by Nawawi al-Bantani.

e. The Position and the Roles of Husbands and Wives ${ }^{20}$

With regard to the positions and roles of husbands and wives in the household, Nawawi al-Bantani stresses that men are leaders, protectors, educators and authority holders for all things in women or wives. In contrast, the wife is described as a dependent individual and fully joins the husband, to the degree that she must view herself as a husband's subservient. For all activities, the wife must ask the husband's blessing, starting from the sunnah fasting, studying, dressing up, going out of the house to just visiting family or to the cemetery, even using her own the assets.

Nawawi al-Bantani interpreted the word of Qawwâmun in Q.s. alNisa [4]: 34 as "Those who have the power to educate". The power is owned by men because they have advantages in many aspects, both naturally which in his discussion is termed as essentially or in religious law is termed al-šhâr'i. Essentially, men have a higher or greater mind than women. Men possess a stronger body that they are more resilient in doing heavy work. Men, in general, are also good at writing and hunting. Because of these things, a number of role are given to men which include positions of the leader of the state (al-imâmah al-uzhma), the leader in prayer (al-imâmah al-Shugrâ), jihâd (war), i(prayer caller), khutbah (sermons), friday prayers, itikâf, testimonies in criminal cases, and Qishâsh. He even added that blood relations were also attributed to men (patrilineal).

Nawawi al-Bantani views that marriage contract does not merely mean to give the please to one party (male or husband), but to both parties, husband and wife. The wife has the right to be exhilarated by

${ }^{20}$ Compare to the rights and obligations of the husband and wife found in article 30-34 of Indonesia Law of Marriage No. 1 of 1974. 
her husband and the husband is obliged to fulfill it and vice versa. So, from this respect, there must be a balance between the spouse. Unfortunately, this view was not reflected in his works as when he talked about the rights and obligations of the wife, al-Bantani tended to position a wife inferior to her husband.

Nawawi al-Bantani, like the majority of Muslim jurists, regarded the marriage as a sunnah or mustahab (highly recommended). He stated that marriage is a mustahab for those who are capable or incapable of dowry and their livelihood. For those who are incapable, however, they are recommended to restrain the desire by fasting. If fasting fails to restrain from the desire, then he is recommended to marry so as to protect him from immoral deeds (adultery).

According to Nawawi al-Bantani, the role of a husband in a household is to be the leader of his family, his wife, and his children. As a leader, a husband will be accountable for the family he leads. He must fulfill their rights such as giving food, clothes, nurturing, educating, and other obligations. While a wife becomes a leader in her husband's house. She must be able to manage her livelihood well, be kind to his husband, and maintain the property of his husband, and his children. As the husband, the wife will also be accountable for her leadership.

In the case of the husband's obligation to his wife, Nawawi al-Bantani quotes among the well-regarded good deed by the religion is: doing good to the wife and not hurting her, providing adequate food and clothing, not hitting her face or saying bad words to her. Beating the wife is justifiable in the case of nusuz (disobedient to God). In fact, in his note ( $f a$-idah), Nawawi al-Bantani asserts: the husband can beat his wife only because she refuses to make as much as her husband wants, or when she refuses on the bed. ${ }^{21}$

f. The Rights and Obligations of Husband and Wives The book 'Uqûd al-Lujain written by Nawawi al-Bantani has been considered in the pesantren community as the most representative

${ }^{21}$ Nawawi, Uqudul Jain (Bandung: al-Marif, n.d.), p. 5. 
book to discuss the rights and obligations of husband and wife. Although there are also other books discussing the similar issue, it is still not enough to get high appreciation and response like the book 'Uqûd al-Lujain does. When people ask about the rights and obligations of the husband and wife the book always becomes the first and foremost reference.

There are 15 themes discussed in 'Uqûd al-Lujain. One theme is addressed to women and men, namely concerning the prohibition of viewing the opposite sex who are not mahram (the forbidden people to marry with), such as a man to a woman and vice versa. Then, there are 4 themes of discussion aimed at men, namely; (1) the rights of the wife to the husband; (2) the reward received by the husband who treats his wife/family well; (3) husband's patience over wife's bad behavior; and (4) recommendations for men to control the family. Following the 4 four themes, there are 9 themes aimed at women, namely: (1) wife's obligation to the husband, (2) the reward of the wife serving the husband; (3) good qualities of wife; (4) the story of women talking with the verse al-Qur'an; (5) Women of the heaven and the hell; (6) the story of the dialogue of the Prophet with his daughter Fatimah r.a.; (7) The importance of female prayer at home; (8) The Prohibition of women with ornamentals when leaving the house, (9) the deviant behaviors of women.

Furthermore, Nawawi al-Bantani lists the wife's rights as husband's obligations and husband's rights as a wife's obligation. In the list, the rights of the wife to the husband include a good treatment, maintenance, dowry, and knowledge of worship and obedience. While the husband's rights to the wife include obedience (except immoral), good behavior, surrender, staying indoors, keeping away from intimacy with others, self-closing including face and palms so as not to be viewed by others except her mahram, not demanding her husband over his ability and not lying about his menstrual period.

Nawawi al-Bantani also raises his concerns about the equality of rights and obligations between men and women. According to his view, verse 6 shows that men and women have the same right to 
demand liability for others as spouses, except for sex issue because in this connection, their rights are different as men are entitled to polygamy.

In addition, the meaning of the verse saying that men have a level upper than a wife, this is related to the right of the husband in return of his responsibility to give dowry and maintenance for his. Thus, the wife is obliged to obey the husband in connection with his responsibility in realizing and maintaining the welfare of the wife.

The words in the Quranic verse 18: bi al-Ma'rûf "Get married with good ways" is parallel with the hadith of the Prophet on Hajj Wada' (farewell / last pilgrimage) wherein he called on men to do good to the people because they were 'awlain (prisoners). As for the way of $M a^{\prime} r \hat{u} f$ (verse 7), which is commonly interpreted as a good way, al-Bantani stresses that in the religious perspective, the word Ma'ruff also means refrain from doing anything that may hurt feelings, either of husbands or wives, even up to the limit of dressing. That is the true meaning of Márûf. ${ }^{22}$

Nawawi al-Bantani also explained that a wife should be shy of her husband, dare not to resist, subjugate her face and view in front of her husband, obedient to her husband when he ordered her to do anything except in evil, silence when husband speaks, invites husband when out of house, reveals his love against a husband when the husband approaches him, pleasing her husband when going to bed, wearing a fragrance, getting used to treating the mouth from an unpleasant smell with spells and fragrances, cleaning clothes, beautifying her body in front of her husband but not when her husband is away from home etc.

To facilitate the readers in tracking the contributions of Nawani al-Bantani in the Indonesia Marriage Law, the following table present the topics of discussion in the Nawawi's thoughts in his fiqh munâkahât which then are implemented in the articles of the Indonesian Marriage Law (UUP) and the Compilation of Islamic Law (KHI).

${ }^{22}$ Nawawi, Al-Tafsir al-Munir Maroh Labid Tafsir al-Nawawi, p. 141. 


\begin{tabular}{|c|c|c|}
\hline No & $\begin{array}{l}\text { Issues Discussed in Fiqh Nawawi } \\
\text { (Nibâyat al-Zain and Taushib } \\
\text { Ala Ibn Qâsim) }\end{array}$ & $\begin{array}{l}\text { Implementation in the Indonesia Law } \\
\text { of Marriage No. } 1 / 1974 \text { and Islamic } \\
\text { Law Compilation (KHI) }\end{array}$ \\
\hline 1 & Marriage Contracts & Articles 27, 28 and 29 of $\mathrm{KHI}$ \\
\hline 2 & $\begin{array}{l}\text { Terms and Conditions of } \\
\text { Marriage }\end{array}$ & Article 14 of KHI \\
\hline 3 & Bridegroom's Approval & $\begin{array}{l}\text { Articles } 6 \text { of UUP } 1974 \text {, article } 16 \text { of } \\
\text { KHI }\end{array}$ \\
\hline 4 & The Minimum age of Marriage & Article 7 of UUP, Article 15 (1) of KHI \\
\hline 5 & $\begin{array}{l}\text { Guardians as a term and } \\
\text { condition of Marriage }\end{array}$ & Articles 26 (1), 19 - 23 of $\mathrm{KHI}$ \\
\hline 6 & Witness of Marriage & Articles 26 (1), 24, 25 and 26 of KHI \\
\hline 7 & Dowry & Articles $30-38$ of KHI \\
\hline 8 & Forbidden Marriage & $\begin{array}{l}\text { Articles } 8-10 \text { of IML, articles } 39-44 \\
\text { of } \mathrm{KHI}\end{array}$ \\
\hline 9 & Kafa'ah (balances) & Article 61 of $\mathrm{KHI}$ \\
\hline 10 & $\begin{array}{l}\text { Rights and Obligations of } \\
\text { Husband and wife }\end{array}$ & $\begin{array}{l}\text { Articles } 30-34 \text { Of UUP, articles } 77-84 \\
\text { of } \mathrm{KHI}\end{array}$ \\
\hline 11 & $\begin{array}{l}\text { The breakup of Marriage and its } \\
\text { Consequences }\end{array}$ & $\begin{array}{l}\text { Articles } 38-41 \text { of UUP, Articles 113- } \\
161 \text { of KHI }\end{array}$ \\
\hline 12 & Iddah/Period of Waiting & $\begin{array}{l}\text { Article } 11 \text { of UUP, article } 39 \text { of PP, } \\
\text { Articles } 153 \text { and } 155 \text { of KHI }\end{array}$ \\
\hline 13 & Hadlonah/Chidcare & Articles 45-49 UUP, Article 156 of KHI \\
\hline 14 & Mut'ah/ Temporary Marriage & Artyicle s 149 (a) and 158- 160 of KHI \\
\hline 15 & $\begin{array}{l}\text { Nafkah Iddah (sustenance } \\
\text { during the Iddah) }\end{array}$ & Article149 (b) of KHI \\
\hline 16 & Rujuk/Reconcilement & Articles 150,163 to 166 of $\mathrm{KHI}$ \\
\hline
\end{tabular}

\section{Conclusion}

Based on the above explanation, it can be concluded that the contributions of Nawawi al- Bantani in Indonesia Marriage Law are mainly the forms of marriage law. This includes the issue of Leadership and the Power of the spouses in the household. According to al-Bantani, the role of a husband in a household is to be the leader of his family, wife, and children. As a leader, he is accountable for the sustenance of his family. He must fulfill their rights such as giving clothes, nurturing, nurturing, educating, getting along well, and other rights. As for the 
wife, she becomes a leader in her husband's house in the sense that she must be able to manage livelihood well, must be kind to his husband, and maintain the property of his husband, and his children. As the husband, the wife is also accountable for her leadership.

The concept of fiqh munâkahât of Nawawi al-Jawi al-Bantani is partly still relevant to the present conditions. His opinions and fatwa have even been adopted into positive law in Indonesia, as in Law No. 1 of 1974 concerning Marriage and Compilation of Islamic Law (KHI) which covers a number of issues in marriage contracts

\section{Bibliograhpy}

A'dlom, Syamsul. 'Kiprah KH.Hasyim Asy'ari dalam Mengembangkan Pendidikan Agama Islam', Jurnal Pusaka, 2 (2014)<http://ejournal. alqolam.ac.id/index.php/jurnal_pusaka/article/view/14>.

Ahmad, Haidlor Ali. 'Kesetaraan Gender dan Pemberdayaan Perempuan di Pondok Pesantren', Penamas (Jurnal Penelitian Agama dan Kemasyarakatan), 2000, 51-61.

. Kesetaraan Gender, and Pemberdayaan Perempuan di Pondok, 'Alhadar, Ivan, Pesantren Between Tradition and Industrial-Urban Challenge in Manfred Oepen and Wolfgang Karcher (Eds.), The Impact of Pesantren in Education and Community Development in Indonesia, Friedrich Naumann Stiftung: Indonesian Society for Pesantren and Community Development P3M): Technical Unversity Berlin, Jakarta, 1998, 99-109.', Jurnal Perempuan, 1999, 7-18.

Al Rahman, Abd. 'Nawawi al-Bantani: an Intellectual Master of The Pesantren Tradition', Studia Islamika, 3 (1996).

Amin, Samsul Munir. Sayyid Ulama Hijaz: Biografi Syaikh Nawawi alBantani. Pustaka Pesantren, 2009.

. 'Syaikh Nawawi Al-Bantani Tokoh Intelektual Pesantren', Manarul Qur'an, 13 (2017), 138-150.

As'ad, Mahrus. 'Pembaruan Pendidikan Islam K.H. Hasyim Asy'ari', TSAQAFAH, 8 (2012), 105-34 <https://doi.org/10.21111/tsaqafah. v8i1.18>. 
Bisri, Mustofa. 'Ini 'Uqûd al-Lujjayn Baru: Ini Baru 'Uqûd al-Lujjayn', in Sinta Nuriyah A. Wahid et al, Wajah Baru Relasi Suami Istri: Telaah Kitab 'Uqûd Al-Lujjayn. Yogyakarta: LKIS, 2001.

Burhanuddin, Hamam. 'Pendidikan Berperspektif Gender di Pesantren', AlMurabbi: Jurnal Studi Kependidikan dan Keislaman, 2 (2015), 111-132. Burhanuddin, Mamat Slamet. 'KH Nawawi Banten (w. 1314/1897) Akar Tradisi Keintelektualan NU', MIQOT: Jurnal Ilmu-Ilmu Keislaman, 34 (2010).

Brockelmann, Carl. 'Al-Nawawi', The Encyclopaedia of Islam. Leiden: Brill Archive, 1954.

Chaer, Moh Toriqul. 'Pesantren dan Pendidikan Gender', Journal Islam Indonesia, 6 (2016), 104-104.

Chaidar. Sejarah Pujangga Islam Syaikh Nawawi, 'al-Bantani Indonesia', Jakarta: CV Sarana Mulia, 1978.

Darban, A. Adaby. 'Ulama Jawa dalam Perspektif Sejarah', Jurnal Humaniora, 16 (2010), 27-34.

Fabriar, Silvia Riskha. 'Potret Perempuan dalam Film Perempuan Berkalung Sorban', Sawwa: Jurnal Studi Gender, 9 (2013), 27-44.

Fatah, Ahmad. 'Mendambakan Paradigma Kesetaraan dalam Pernikahan (Telaah Kritis Terhadap Kitab Uqud al-Lujjain)', Jurnal Penelitian, 8 (2014) <https://doi.org/10.21043/jupe.v8i2.842>.

Hamid, Abdul Hamid Abdul. 'Memetakan Aktor Politik Lokal Banten Pasca Orde Baru: Studi Kasus Kiai dan Jawara di Banten', POLITIKA: Jurnal Ilmu Politik, 1 (2013), 32-45.

Hidayatulloh, Muhammad Ridwan, Aceng Kosasih, and Fahrudin Fahrudin. 'Konsep Tasawuf Syaikh Nawawi al-Bantani dan Implikasinya Terhadap Pendidikan Agama Islam di Persekolahan', Tarbawy : Indonesian Journal of Islamic Education, 2 (2015), 1-15. <https://doi.org/10.17509/t.v2i1.3373>.

Hodgson, Marshall GS. The Venture of Islam: Iman dan Sejarah dalam Peradaban Dunia. Jakarta: Paramadina, 2012.

Hudaeri, Mohamad. 'Tasbih dan Golok: Studi Tentang Kharisma Kyai \& Jawara di Banten', Istiqro, 2 (2003), 57-87. 
Hurgronje, Snouck. Mekka in the Latter Part of the 19th Century: Daily Life, Customs and Learning. The Moslims of the East-Indian Archipelago. Leidein: BRILL, 2006.

Ichwan, Moch Nur. 'The Local Politics of Orthodoxy: The Majelis Ulama Indonesia in the Post-New Order Banten', Journal of Indonesian Islam, 6 (2012), 166-194.

El Saha, Ishom. Intelektualisme Pesantren: Potret Tokoh dan Cakrawala Pemikiran di Era Pertumbuhan Pesantren. Yogyakarta: Diva Pustaka, 2003.

Kartodirdjo, Sartono. 'Le Leadership Dans La Révolte Des Paysans de Banten, 1888', Archipel, 50 (1995), 123-130.

Khuluq, Lathiful. 'K.H. Hasyim Asy'ari's Contribution to Indonesian Independence', Studia Islamika, 5 (1998) <https://doi.org/10.15408/ sdi.v5i1.760>.

Lombard, Denys. 'Zamakhsyari Dhofier. Tradisi Pesantren, Studi Tentang Pandangan Hidup Kyai', Archipel, 28 (1984), 220-220.

Lubis, Nina Herlina. Banten dalam Pergumulan Sejarah: Sultan, Ulama, Jawara. Jakarta: LP3ES, 2004.

Lathiful Khuluk. Fajar Kebangunan Ulama: Biografi KH. Hasyim Asy'ari. Yogyakarta: LKiS Pelangi Aksara, 2000.

Mahmudi, Zaenul. 'Fikih di Pesantren Salaf (Strategi Pengembangan Fikih Salaf di Pesantren Hidayatul Mubtadi'in Lirboyo Kediri)', El-QUDWAH, 2012.

Mardhiyyah, Ainaul. 'Konstruksi Seksualitas Perempuan dalam Literatur Pesantren Klasik: (Studi Terhadap Kitab Uqud al-Lujjayn Karya Nawawi al-Bantani)', Palastren Jurnal Studi Gender, 6 (2016), 57-88 <https://doi.org/10.21043/palastren.v6i1.978>.

Mas'ud, Abdurrachman. Dari Haramain ke Nusantara: Jejak Intelektual Arsitek Pesantren. Jakarta: Kencana, 2006.

Muhammad, Husein. 'Figh Perempuan', Refleksi Kiai Atas Wacana Agama dan Jender. Yogyakarta: LKiS Kerjasama dengan Rahima dan Ford Foundation, 2001. . 'Kajian Atas Kitab Uqud al-Lujain', Tashwirul Afkar, 1999, 94-100 
Muslim, Asep, Lala M. Kolopaking, Arya H. Dharmawan, and Endriatmo Soetarto. 'Dinamika Peran Sosial Politik Ulama dan Jawara di Pandeglang Banten', MIMBAR, Jurnal Sosial Dan Pembangunan, 31 (2015), 461-474.

Nawawi. Uqudul Jain. Bandung: Al-Maarif, n.d. al-Tafsir al-Munir Maroh Labid Tafsir al-Nawawi. Bayrut: Dar Ihya al-Kutub al-Arabiyah, n.d.

. Nihâyat al-Zain Fi Irsyâd al-Mubtadiîn. N.p. Dar Ihya al-Kutub al-Arabiya, n.d.

Pransiska, Toni, 'Pendidikan Islam Transformatif Syeikh Nawawi alBantani: Upaya Mewujudkan Generasi Religius-Saintifik', Jurnal Ilmiah Didaktika: Media Ilmiah Pendidikan dan Pengajaran, 18 (2018), 172-188.

Rodiana, Yuyun. Nawawi al-Bantani: Riwayat Hidup dan Sumbanganya Terhadap Islam. Jakarta: Skripsi S1, Fakultas Sastra Universitas Indonesia, 1990.

Srimulyani, Eka. 'Muslim Women and Education in Indonesia: The Pondok Pesantren Experience', Asia Pacific Journal of Education, 27 (2007), 85-99.

Steenbrink, Karel A. Beberapa Aspek tentang Islam di Indonesia Abad ke19. Jakarta: Bulan Bintang, 1984.

Sulaiman, Sukhairu. 'al-Qira’at al-Mutawatirah dan Kesannya Terhadap Pentafsiran Al-Qur'an: Kajian Terhadap Kitab Marah Labid Li Kashf Ma'na al-Qur'an al-Majid Karangan Nawawi al-Bantani Tumpuan Terhadap Surah Al-Baqarah (unpublished masters, University of Malaya, 2013) <http://studentsrepo.um.edu.my/5323/>.

Suwarjin. 'Kitab Syarah dan Tradisi Intelektual Pesantren', Jurnal Ilmiah Mizani: Wacana Hukum, Ekonomi dan Keagamaan, 4 (2018)

Wahid, Abdurrahman, and Sinta Nuriyah. Wajah Baru Relasi Suami Isteri: Telaah Kitab 'Uqud al-Lujjayn. Yogyakarta: LKiS, 2001. 